\title{
Upaya Meningkatkan Keaktifan Dan Prestasi Belajar IPA Melalui Pembelajaran Daring Berbasis Whatsapp Group Pada Siswa Kelas IX SMP Negeri 1 Buntulia Semester 2 Tahun Pelajaran 2020/2021
}

\author{
Aryuningsih I.Abd.Rahman Zakaria \\ SMP Negeri 1 Buntulia \\ Aryuningsihzakaria28@Gmail.Com
}

\author{
Received: 13 August 2021; Revised: 02 October 2021; Accepted: 22 December 2021 \\ DOI: http://dx.doi.org/10.37905/aksara.8.1.491-502.2022
}

\begin{abstract}
Abstrak
Tujuan dari penelitian ini adalah meningkatkan keaktifan dan prestasi belajar siswa pada pembelajaran IPA dengan pembelajaran daring berbasis Whatsapp Group. Jenis penelitian adalah penelitian tindakan sekolah yang dilaksanakan dalam 2 siklus dan pada masing-masing siklus terdiri dari 2 kali pertemuan dengan empat tahapan yaitu (1) perencanaan, (2) pelaksanaan tindakan, 3) observasi, (4) refleksi. Subjek penelitian adalah kelas IX SMP Negeri . 1 Buntulia dengan jumlah 18 siswa. Teknik pengumpulan data menggunakan teknik tes, observasi dan dokumentasi. Validasi data dilakukan dengan triangulasi. Analisis data yang digunakan dalam penelitian ini adalah analisis diskriptif teknik persentasi. Hasil penelitian menunjukkan bahwa peningkatan keaktifan siswa pada studi awal hanya 6 siswa atau 33,33\%, naik menjadi 12 siswa atau $66,67 \%$ pada siklus pertama, dan $100 \%$ atau 18 siswa pada siklus kedua. Hal tersebut didukung pula oleh kenaikan hasil belajar siswa dari rata-rata pada studi awal hanya 57,78 naik menjadi 67,72 pada siklus pertama, dan 77,22 pada siklus kedua, dengan tingkat ketuntasan belajar sebanyak 3 siswa (16,67\%)pada studi awal, 66,67\% atau 12 siswa pada siklus pertama, 16 siswa atau 88,89\% pada siklus kedua sehingga dapat simpulkan bahwa semua indikator dan kriteria keberhasilan proses perbaikan pembelajaran telah terpenuhi dan tercapai pada siklus kedua. Dari data tersebut terlihat bahwa penerapan pembelajaran daring berbasis Whatsapp Group terbukti dapat meningkatkan keaktifan dan prestasi belajar IPA siswa kelas IX SMP Negeri. 1 Buntulia Semester 2 Tahun Pelajaran 2020/2021.
\end{abstract}

Kata Kunci: Whatsapp Group, keaktifan, prestasi belajar

\section{PENDAHULUAN}

Sejak munculnya wabah virus Covid-19 di Indonesia, dampak bagi keberlangsungan pendidikan yang disebabkan oleh pandemi ini sangat dirasakan oleh masyarakat berdomisili di kota maupun di desa (Halal, 2020). Menurut Kemendikbud RI (2020), memutuskan bahwa seluruh kegiatan pembelajaran selama pandemi dilakukan secara daring (dalam jaringan). Berdasarkan Surat Edaran Nomor 4 Tahun 2020, tentang Pelaksanaan Kebijakan Pendidikan dalam Masa Darurat Penyebaran Coronavirus Disease (Covid-19), yang memuat pemberitahuan maupun arahan tentang pelaksanaan kegiatan pembelajaran dari rumah bagi seluruh jenjang pendidikan mulai dari pra-sekolah hingga perguruan tinggi.

Maraknya pandemi COVID-19 di Indonesia memberikan efek negatif yang besar terhadap sektor pendidikan di dalamnya. Meredam dampak COVID-19 tersebut, maka dibutuhkan langkah-langkah yang strategis. Pertama yang perlu dilakukan adalah memberikan edukasi kepada para peserta didik dan praktisi pendidik. Dilakukan dengan sosialisasi secara intensif oleh dinas kesehatan tentang virus corona itu sendiri, baik dari aspek pencegahannya maupun cara menyikapinya. Wawasan ini diharapkan dapat 
mengurangi efek kekhawatiran berlebih yang dapat menyebabkan dampak traumatis pada peserta didik dan tentu juga para pendidik.

Sebagian besar lembaga pendidikan sudah menerapkan sistem Pembelajaran Jarak Jauh (PJJ). Pola pengajaran ini mengikuti rekomendasi pemerintah yang harus dilaksanakan secara daring. Pembelajaran Jarak Jauh (PJJ) bisa menjadi solusi agar pembahasan materi dapat terus berlanjut (Fermiska dkk., 2020). Langkah selanjutnya yang harus dilakukan adalah pemanfaatan teknologi jaringan dan informasi dengan menggunakan internet atau social media. Di Indonesia, persentase pengguna internet mencapai hingga 64\% dari kalangan remaja usia 15-19 tahun. Pada umumnya, rentang usia ini cenderung diminati oleh kalangan pelajar (Pranajaya, 2018). Whatsapp Group merupakan alat untuk berkomunikasi yang sangat populer di kalangan pelajar, seluruh interaksi dapat dilakukan seperti, mengirim pesan, foto, audio, dan video. Dengan menggunakan aplikasi ini, proses pembelajaran jarak jauh tetap berlangsung dan berjalan dengan baik, sehingga tujuan pembelajaran yang akan dicapai dapat terwujud (Andi, 2018).

Salah satu alternatif pembelajaran jarak jauh atau daring yaitu dengan pembelajaran e-learning. Pembelajaran e-learning dapat menunjang pendidik serta peserta didik untuk mengatasi aturan sosial distancing yang diterapkan oleh pemerintah pusat maupun daerah terkait pendemi Covid 19. Dikarenakan pembelajaran e-learning memiliki berbagai kelebihan di antaranya akses yang tidak terbatas oleh jarak, tempat dan waktu salah satunya dengan menggunakan Whatsapp Group.

Melihat kondisi realita yang ada, ketika mengadakan observasi di SMP Negeri 1 Buntulia dalam mengikuti pembelajaran daring khususnya pelajaran IPA kelas IX perlu adanya perhatian. Penggunaan metode penugasan mendominasi pelaksanaan kegiatan pembelajaran daring tersebut. Metode tersebut disampaikan secara terus menerus digunakan pada setiap pembelajaran sehingga mengakibatkan motivasi peserta didik rendah, jenuh dan kurang antusias dalam mengikuti pelajaran IPA sehingga prestasi belajar yang diperoleh siswa kelas IX dalam pembelajaran cenderung rendah. Nilai IPA pada kegiatan pra-siklus menunjukkan angka yang kurang memuaskan hanya terdapat 3 siswa $(16,67 \%)$ yang dinyatakan tuntas dengan perolehan nilai rata-rata secara klasikal sebesar 57,78 .

Berdasarkan penjelasan di atas, peneliti akan mencoba memecahkan masalah dengan menerapkan metode pembelajaran daring yang dapat meningkatkan keaktifan siswa dan memperdalam pengetahuan siswa tentang materi belajar IPA yaitu dengan menggunakan e-learning berbasis Whatsapp Group. Penggunaan aplikasi Whatsapp Group diharapkan membuat siswa menjadi lebih ekspresif dengan membuat status, upload foto dengan caption yang tekadang aneh bahkan juga memotivasi dan berbagi video. Siswa juga mencoba memanfaatkan media sosial Whatsapp Group untuk saling mengingatkan kepada sesama teman agar mengerjakan tugas yang diberikan oleh Guru. Ada pula yang saling menyemangati satu sama lain melalui status Whatsapp Group dalam hal belajar agar motivasi untuk belajar terbentuk. Fitur Whatsapp Group juga dimanfaatkan oleh para pendidik, seperti fitur dokumen. Pendidik menggunakan fitur tersebut dengan mengirimkan bacaan yang bermanfaat atau materi pelajaran yang akan dipelajari maupun yang sudah dipelajari di dalam Whatsapp Group untuk kemudian dibaca dan dipelajari oleh siswa. Diharapkan Whatsapp Group dapat menjadi media pembelajaran yang baik serta untuk memotivasi belajar untuk para penggunanya, 
AKSARA: Jurnal Ilmu Pendidikan Nonformal

P-ISSN 2407-8018 E-ISSN 2721-7310 DOI prefix $\underline{10.37905}$

Volume 08, (1), January 2022

http://ejurnal.pps.ung.ac.id/index.php/Aksara

\section{KAJIAN PUSTAKA}

\section{Keaktifan Belajar}

Menurut Anton M. Mulyono (2001 : 26) keaktifan adalah kegiatan atau aktivitas atau segala sesuatu yang dilakukan atau kegiatankegiatan yang terjadi baik fisik maupun non fisik. Menurut Sanjaya (2007:101-106) aktivitas tidak hanya ditentukan oleh aktivitas fisik semata, tetapi juga ditentukan oleh aktivitas non fisik seperti mental, intelektual dan emosional. Keaktifan yang dimaksudkan di sini penekanannya adalah pada siswa, sebab dengan adanya keaktifan siswa dalam proses pembelajaran akan tercipta situasi belajar aktif.

Menurut Rochman Natawijaya (dalam Depdiknas 2005: 31) belajar aktif adalah suatu sistem belajar mengajar yang menekankan keaktifan siswa secara fisik, mental intelektual dan emosional guna memperoleh hasil belajar yang berupa perpaduan antara aspek kognitif, afektif, dan psikomotor. Belajar aktif sangat diperlukan oleh siswa untuk mendapatkan hasil belajar yang maksimum. Ketika siswa pasif atau hanya menerima informasi dari guru saja, akan timbul kecenderungan untuk cepat melupakan apa yang telah diberikan oleh guru, oleh karena itu diperlukan perangkat tertentu untuk dapat mengingatkan yang baru saja diterima dari guru.

\section{Prestasi Belajar}

Belajar adalah suatu kegiatan yang dilakukan dengan melibatkan dua unsur, yaitu jiwa dan raga. Belajar adalah serangkaian kegiatan jiwa dan raga untuk memperoleh perubahan tingkah laku sebagai hasil dari pengalaman individu dalam interaksi dengan lingkungan yang menyangkut aspek kognitif, afektif, dan psikomotorik. Gerak raga yang ditunjukkan harus sejalan dengan proses jiwa untuk mendapatkan perubahan (Syaiful 2002: 13). Sementara itu Slameto (2003: 2) mendefinisikan belajar sebagai suatu proses usaha yang dilakukan seseorang untuk memperoleh suatu perubahan tingkah laku yang secara keseluruhan, sebagai hasil pengalamannya sendiri dalam interaksi dengan lingkungannya.

\section{Pembelajaran Daring}

a. Pengertian Pembelajaran Daring /Internet Learning

Istilah daring merupakan akronim dari "dalam jaringan" yaitu suatu kegiatan yang dilaksanakan dengan sistem daring yang memanfaatkan internet. Menurut Bilfaqih \& Qomarudin (2015:1) "pembelajaran daring merupakan program penyelenggaraan kelas pembelajaran dalam jaringan untuk menjangkau kelompok target yang masif dan luas". Thorme dalam Kuntarto (2017:102) "pembelajaran daring adalah pembelajaran yang menggunakan teknologi multimedia, kelas virtual, CD ROM, streaming video, pesan suara, email dan telepon konferensi, teks online animasi, dan video streaming online”. Sementara itu Rosenberg dalam Alimuddin, Tawany \& Nadjib (2015:338) menekankan bahwa e-learning merujuk pada penggunaan teknologi internet untuk mengirimkan serangkaian solusi yang dapat meningkatkan pengetahuan dan keterampilan. Menurut Ghirardini dalam Kartika (2018:27) "daring memberikan metode pembelajaran yang efektif, seperti berlatih dengan adanya umpan balik terkait, menggabungkan kolaborasi kegiatan dengan belajar mandiri, personalisasi pembelajaran berdasarkan kebutuhan mahasiswa dan menggunakan simulasi dan permainan". Sementara itu menurut 
Permendikbud No. 109/2013 pendidikan jarak jauh adalah proses belajar mengajar yang dilakukan secara jarak jauh melalui penggunaan berbagai media komunikasi.

b. Karakteristik/ciri-ciri Pembelajaran Daring/ E-Learning.

Tung dalam Mustofa, Chodzirin, \& Sayekti (2019:154) menyebutkan karakteristik dalam pembelajaran daring antara lain:

1) Materi ajar disajikan dalam bentuk teks, grafik dan berbagai elemen multimedia,

2) Komunikasi dilakukan secara serentak dan tak serentak seperti video conferencing, chats rooms, atau discussion forums,

3) Digunakan untuk belajar pada waktu dan tempat maya,

4) Dapat digunakan berbagai elemen belajar berbasis CD-ROM untuk meningkatkan komunikasi belajar,

5) Materi ajar relatif mudah diperbaharui,

6) Meningkatkan interaksi antara mahasiswa dan fasilitator,

7) Memungkinkan bentuk komunikasi belajar formal dan informal,

8) Dapat menggunakan ragam sumber belajar yang luas di internet

c. Manfaat Pembelajaran Daring/ E-Learning.

Bilfaqih dan Qomarudin (2105: 4) menjelaskan beberapa manfaat dari pembelajaran daring sebagai beikut :

1) Meningkatkan mutu pendidikan dan pelatihan dengan memanfaatkan multimedia secara efektif dalam pembelajaran.

2) Meningkatkan keterjangkauan pendidikan dan pelatihan yang bermutu melalui penyelenggaraan pembelajaran dalam jaringan.

3) Menekan biaya penyelenggaraan pendidikan dan pelatihan yang bermutu melalui pemanfaatan sumber daya bersama.

\section{Whatsapp}

WhatsApp merupakan aplikasi yang dirancang untuk mempermudah komunikasi di tengah perkembangan teknologi saat ini. WhatsApp merupakan bagian dari media sosial yang memudahkan dan memungkinkan semua penggunanya dapat berbagi informasi. Pengguanaan WhatsApp telah dimanfaatkan oleh berbagai kalangan masyarakat karena pengunaannya yang mudah. Seiring dengan pendapat Jumiatmoko (2016:53) bahwa WhatsApp merupakan aplikasi berbasis internet yang memudahkan penggunanya dalam berkomunikasi dengan fitur-fitur yang tersedia serta merupakan media sosial yang paling populer digunakan dalam berkomunikasi. $83 \%$ dari 171 juta pengguna internet adalah pengguna WhatsApp (Astini,2020:19).

Suryadi (2018:5) menyatakan bahwa “ WhatsApp merupakan sarana dalam berkomunikasi dengan saling bertukar informasi baik pesan teks, gambar, video bahkan telepon." Pendapat tersebut dapat diketahui bahwa WhatsApp memberikan kemudahan dalam menyampaikan suatu informasi. Pendapat Afnibar (2020: 73) yang menyatakan penggunaan WhatsApp akan mempermudah penggunanya untuk menyampaikan suatu informasi secara lebih cepat dan efektif. Jadi WhatsApp dapat memberikan keefektifitasan dalam berkomunikasi, berinteraksi dengan mudah dan cepat terutama dalam menyampaian informasi pembelajaran. 


\section{METODE PENELITIAN}

Penelitian Tindakan kelas ini dilaksanakan di SMP Negeri 1 Buntulia yang beralamat di Jl.Gunung Pani No.125 Desa Taluduyunu Utara Kec.Buntulia Kabupaten Pohuwato Provinsi Gorontalo.

Sedangkan waktu penelitian dimulai sejak awal sampai dengan pertengahan semester ganjil tahun pelajaran 2020/2021 atau mulai bulan Januari 2021 sampai dengan Maret 2021. Subjek penelitian tindakan kelas ini adalah siswa kelas IX SMP Negeri 1 Buntulia Semester 2 tahun pelajaran 2020/2021 yang jumlah siswanya 18 orang.

Pengumpulan data pada penelitian ini dilakukan dengan menggunakan teknik yaitu: observasi, tes, metode dokumentasi

\section{HASIL PENELITIAN DAN PEMBAHASAN}

\section{a. Deskripsi Data}

\section{Kondisi Awal}

Peneliti menemukan masalah dengan hasil pembelajaran IPA yang dianggap kurang optimal dan belum mencapai tujuan pembelajaran yang diharapkan. Hasil peneliti, pengamatan kondisi awal siswa kelas IX SMP Negeri 1 Buntulia pada pelajaran IPA dengan menggunakan pedoman pengamatan dan alat pengumpul data menunjukan bahwa nilai siswa masih rendah. Hal ini dapat dibuktikan dengan skor nilai rata-rata siswa masih di bawah KKM yaitu (75)

Penjelasan mengenai kondisi awal hasil pembelajaran sebagaimana tabel di bawah ini:

\section{Rekapitulasi Nilai Tes Formatif Pada Kondisi Awal}

\begin{tabular}{|l|l|l|l|l|}
\hline \multirow{2}{*}{ No } & \multirow{2}{*}{ Kriteria Ketuntasan } & \multicolumn{2}{|l|}{ Kondisi Awal } & \multirow{2}{*}{ Ket } \\
\cline { 3 - 4 } & & Jumlah & $\mathbf{\%}$ & \\
\hline $\mathbf{1}$ & Tuntas & 3 & 16.67 & \\
\hline $\mathbf{2}$ & Belum Tuntas & 15 & 83.33 & \\
\hline Jumlah & $\mathbf{1 8}$ & $\mathbf{1 0 0}$ & \\
\hline Nilai terendah & 40.00 & \\
\hline Nilai tertinggi & 80.00 & \\
\hline Rata - rata & 57.78 & \\
\hline Ketuntasan & 3 & \\
\hline \% Ketuntasan & 16.67 & \\
\hline
\end{tabular}

\section{Siklus I}

Tahap ini menerapkan rencana penelitian tindakan kelas yang telah disusun pada tahap perencanaan sesuai dengan pembelajaran daring berbasis Whatsapp Group . Prosedur pelaksanaannya adalah sebagai berikut:

Dari hasil pelaksanaan tindakan pada siklus pertama dengan menerapkan pembelajaran daring berbasis Whatsapp Group pada pembelajaran IPA dapat diperoleh dan disimpulkan data-data sebagai berikut :

\section{Rekapitulasi Nilai Tes Formatif Pembelajaran pada Siklus Pertama}




\begin{tabular}{|c|c|c|c|c|}
\hline \multirow{2}{*}{ No } & Kriteria & \multicolumn{2}{|c|}{ Kondisi Awal } & \multirow{2}{*}{ Ket } \\
\cline { 3 - 4 } & Ketuntasan & Jumlah & \% & \\
\hline & Tuntas & 12 & 66.67 & \\
\hline $\mathbf{2}$ & Belum Tuntas & 6 & 33.33 & \\
\hline \multicolumn{2}{|c|}{ Jumlah } & $\mathbf{1 8}$ & $\mathbf{1 0 0}$ & \\
\hline \multicolumn{2}{|c|}{ Nilai terendah } & $\mathbf{5 0 . 0 0}$ & \\
\hline Nilai tertinggi & $\mathbf{8 0 . 0 0}$ & \\
\hline Rata - rata & $\mathbf{6 7 . 2 2}$ & \\
\hline Ketuntasan & $\mathbf{1 2}$ & \\
\hline \% Ketuntasan & $\mathbf{6 6 . 6 7}$ & \\
\hline
\end{tabular}

Dari tabel di atas tentang rekapitulasi nilai tes formatif pembelajaran IPA di atas dapat diterangkan 12 siswa atau 66,67\% yang mengalami kenaikan nilai prestasi atau dinyatakan tuntas, sedangkan sisanya sebanyak 6 siswa atau 33,33\% dinyatakan belum tuntas belajarnya.

Melihat hasil di atas maka peneliti bersama-sama dengan observer sepakat untuk melanjutkan pelaksanaan perbaikan pembelajaran pada siklus II karena perolehan nilai rata-rata hasil belajar secara klasikal baru mencapai 67,22 dan ketuntasan belajar secara klasikal baru mencapai angka 66,67\%, dengan harapan pada siklus II rata-rata hasil belajar siswa dapat mencapai perolehan di atas KKM sebesar 70,00 sesuai dengan kriteria keberhasilan yang telah ditetapkan dan tingkat ketuntasan belajar mencapai angka di atas $85 \%$ dari jumlah seluruh siswa

\section{Siklus II}

Menerapkan rencana penelitian tindakan kelas yang telah disusun pada tahap perencanaan siklus II sesuai pembelajaran daring berbasis Whatsapp Group dengan RPP yang lebih inovatif. Prosedur pelaksanaannya adalah sebagai berikut:

Dari hasil pelaksanaan tindakan pada siklus kedua dengan menerapkan pembelajaran daring berbasis Whatsapp Group pada pembelajaran IPA dapat diperoleh dan disimpulkan data-data sebagai berikut:

TRekapitulasi Nilai Tes Formatif Pembelajaran pada Siklus Kedua

\begin{tabular}{|c|l|l|l|l|}
\hline \multirow{2}{*}{ No } & Kriteria & \multicolumn{2}{|l|}{ Kondisi Awal } & \multirow{2}{*}{ Ket } \\
\cline { 3 - 4 } & Ketuntasan & umlah $\%$ & \\
\hline
\end{tabular}




\begin{tabular}{|l|l|l|l|l|}
\hline $\mathbf{1}$ & Tuntas & 16 & 88.89 & \\
\hline $\mathbf{2}$ & $\begin{array}{c}\text { Belum } \\
\text { Tuntas }\end{array}$ & 2 & 11.11 & \\
\hline Jumlah & $\mathbf{1 8}$ & $\mathbf{1 0 0}$ & \\
\hline Nilai terendah & $\mathbf{6 0 . 0 0}$ & \\
\hline Nilai tertinggi & $\mathbf{9 0 . 0 0}$ & \\
\hline Rata - rata & $\mathbf{7 7 . 2 2}$ & \\
\hline Ketuntasan & $\mathbf{1 6}$ & \\
\hline \% Ketuntasan & $\mathbf{8 8 . 8 9}$ & \\
\hline
\end{tabular}

Dari tabel di atas dapat diterangkan bahwa pada siklus II nilai rata-rata hasil belajar 77,22, jumlah siswa yang telah mencapai tingkat ketuntasan belajar 16 siswa $(88,89 \%)$, dan pada siklus kedua, sedangkan masih ada 2 siswa yang tidak tuntas $(11,11 \%)$, sehingga dapat disimpulkan bahwa semua siswa dinyatakan tuntas belajarnya pada siklus kedua. Melihat hasil di atas maka peneliti bersama-sama dengan observer menyimpulkan bahwa hasil tes hasil belajar menunjukkan hasil 77,22. Hal ini menunjukkan bahwa tes hasil belajar sudah memenuhi kriteria keberhasilan karena hasil belajar berada di atas angka kriteria minimal ketuntasan (KKM) sebesar 70, dengan jumlah siswa yang telah tuntas belajarnya sebanyak 16 siswa atau 88,89\%.

\section{Hasil Belajar}

Setelah melakukan analisa terhadap data yang peroleh dari dua siklus yang dilaksanakan maka dapat dapat disimpulkan bahwa penggunaan pembelajaran daring berbasis Whatsapp Group pada pembelajaran menunjukkan peningkatan yang signifikan terhadap hasil proses pembelajaran.

Rekapitulasi Prestasi Belajar Siswa pada Kondisi Awal, Siklus I dan Siklus
\begin{tabular}{|l|l|r|l|l|l|l|}
\hline No & Pembelajaran & \multicolumn{6}{|c|}{ Hasil Belajar Siswa } \\
\cline { 3 - 7 } & & $\begin{array}{c}\text { Nilai Rata- } \\
\text { Rata Kelas }\end{array}$ & & & & \\
\hline 1. & Awal & 57.78 & 3 & 16.67 & 15 & 83.33 \\
\hline $\mathbf{2 .}$ & Siklus I & 67.22 & 12 & 66.67 & 6 & 33.33 \\
\hline 3. & Siklus II & 77.22 & 16 & 88.89 & 2 & 11.11 \\
\hline
\end{tabular}

Dari penjelasan pada tabel di atas, diperoleh keterangan pada kondisi awal nilai rata-rata sebesar 57,78 dengan siswa tuntas sebanyak 3 siswa atau 16,67\%, siklus pertama nilai rata-rata sebesar 67,22 dengan siswa tuntas sebanyak 12 siswa atau 66,67\%, dan siklus kedua nilai rata-rata sebesar 77,22 dengan siswa tuntas sebanyak 16 siswa atau 88,89\%.

Untuk lebih jelasnya peningkatan hasil belajar siswa dan nilai rata-rata hasil belajar serta ketuntasan belajar dapat dilihat pada gambar diagram batang berikut ini :

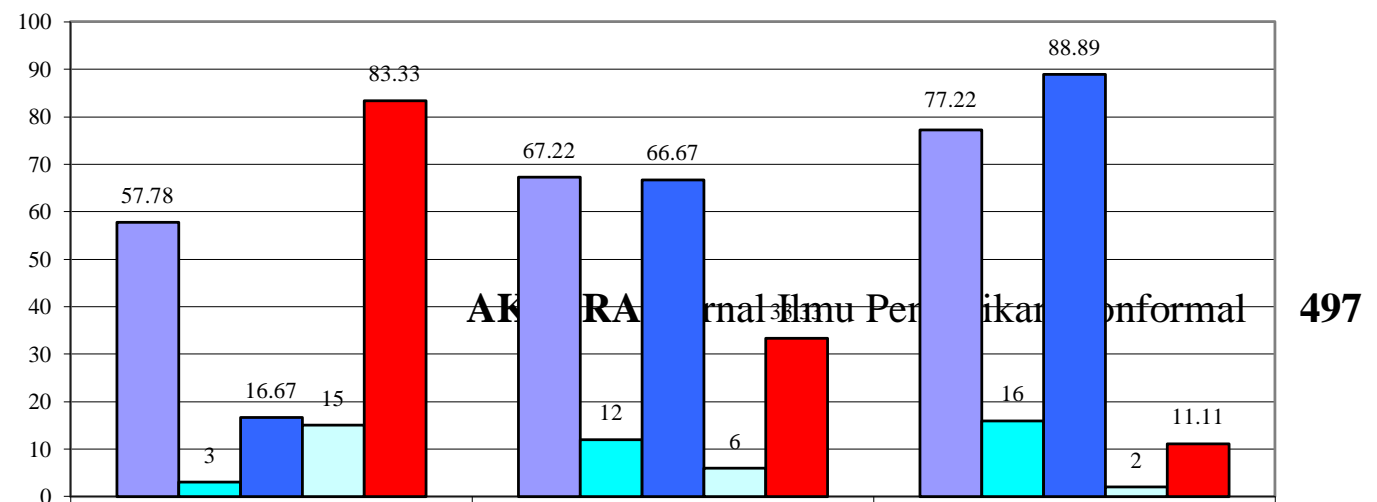




\section{Diagram Peningkatan Nilai dan Ketuntasan Belajar pada Kondisi Awal, Siklus I dan Siklus II}

\section{Pembahasan Hasil Penelitian}

Dari hasil temuan data hasil observasi dan tes formatif siswa mulai dari studi awal sampai dengan perbaikan pembelajaran pada siklus II, terlihat jelas adanya peningkatan penguasaan materi pada siswa terhadap pembelajaran mata pelajaran Ilmu Pengetahuan Alam (IPA). Hal itu menunjukkan daya serap siswa meningkat yang tercermin dalam kemampuan memahami materi belajar. Dengan meningkatnya daya serap maka meningkat pula penguasaan materi yang berdampak positif terhadap ketuntasan belajar siswa.

Pada siklus pertama, perolehan nilai rata-rata hasil belajar secara klasikal baru mencapai 67,22 dari kondisi awal sebesar 57,78 dan ketuntasan belajar secara klasikal baru mencapai angka 66,67\% atau 12 siswa dari kondisi awal sebesar 16,67\% atau 3 siswa dengan harapan pada siklus II rata-rata hasil belajar siswa dapat mencapai perolehan di atas KKM minimal sebesar 70 sesuai dengan kriteria keberhasilan yang telah ditetapkan dan tingkat ketuntasan belajar mencapai angka di atas $85 \%$ dari jumlah seluruh siswa. Adapun penjelasan mengenai keaktifan belajar siswa pada siklus pertama sebanyak 16 siswa atau 66,67\% dari kondisi awal sebesar 33,33\% atau 6 siswa.

Oleh karena itu akan dilanjutkan kembali dengan mengadakan perbaikan pada siklus kedua. Dalam proses perbaikan pembelajaran pada siklus kedua nilai rata-rata hasil belajar 77,22, jumlah siswa yang telah mencapai tingkat ketuntasan belajar 16 siswa $(88,89 \%)$, dan pada siklus kedua, 2 siswa yang tidak tuntas $(11,11 \%)$, sehingga dapat disimpulkan bahwa lebih dari $85 \%$ siswa dinyatakan tuntas belajarnya pada siklus kedua. Melihat hasil di atas maka peneliti bersama-sama dengan observer menyimpulkan bahwa hasil tes hasil belajar menunjukkan hasil 77,22. Hal ini menunjukkan bahwa tes hasil belajar sudah memenuhi kriteria keberhasilan karena hasil belajar berada di atas angka kriteria minimal ketuntasan (KKM) sebesar 70, dengan jumlah siswa yang telah tuntas belajarnya sebanyak 16 siswa atau 88,89\%.

Angka tersebut menunjukkan bahwa pelaksanaan perbaikan pembelajaran telah memenuhi kriteria ketuntasan, demikian pula halnya dengan peningkatan keaktifan belajar yang menunjukkan angka 100\%, sehingga pembelajaran dapat dilanjutkan ke materi selanjutnya, dan kepada siswa yang belum tuntas akan diberikan program remidial selama beberapa hari yang dilaksanakan setiap akhir kegiatan pembelajaran.Dengan demikian perbaikan pembelajaran Ilmu Pengetahuan Alam (IPA) melalui penelitian tindakan kelas dengan pembelajaran daring berbasis Whatsapp Group dari studi awal 
sampai dengan perbaikan pembelajaran siklus II, telah mengalami ketuntasan sampai100\%.

\section{KESIMPULAN}

Berdasarkan penelitian yang telah dilakukan, maka dapat diambil kesimpulan sebagai berikut :

1. Penggunaan pembelajaran daring berbasis Whatsapp Group dapat meningkatkan keaktifan siswa kelas IX SMP Negeri 1 Buntulia pada pembelajaran IPA Peningkatan keaktifan siswa menunjukkan perolehan pada studi awal hanya 6 siswa atau 33,33\%, naik menjadi 12 siswa atau 66,67\% pada siklus pertama, dan $100 \%$ atau 18 siswa pada siklus kedua.

2. Penggunaan pembelajaran daring berbasis Whatsapp Group dapat meningkatkan prestasi belajar siswa kelas IX SMP Negeri 1 Buntulia pada pembelajaran IPA. Dari dua siklus pelaksanaan perbaikan pembelajaran yang dilaksanakanhasil belajar siswa menunjukkan kenaikan yang signifikan. Peningkatan hasil belajar siswa dari rata-rata pada studi awal hanya 57,78 naik menjadi 67,72 pada siklus pertama, dan 77,22 pada siklus kedua, dengan tingkat ketuntasan belajar sebanyak 3 siswa (16,67\%)pada studi awal, 66,67\% atau 12 siswa pada siklus pertama, 16 siswa atau 88,89\% pada siklus kedua sehingga dapat simpulkan bahwa semua indikator dan kriteria keberhasilan proses perbaikan pembelajaran telah terpenuhi dan tercapai pada siklus kedua.

\section{SARAN}

Dari hasil penelitian yang telah dilakukan di kelas IX SMP Negeri 1 Buntulia peneliti dapat memberikan beberapa saran sebagai berikut:

1. Bagi siswa

a. Agar supaya selalu fokus dalam mengikuti pelajaran supaya hasilnya lebih optimal.

b. Setiap siswa hendaknya dapat menjalin hubungan baik dengan guru agar proses belajar mengajar terasa nyaman dan menyenangkan.

2. Bagi guru

a. Dapat dijadikan masukan bagi guru dalam menentukan strategi pembelajaran IPA dalam rangka meningkatkan prestasi belajar siswa.

b. Penggunaan metode pembelajaran yang bervariasi harus terus ditingkatkan agar dapat menciptakan pembelajaran yang menyenangkan bagi siswa.

\section{DAFTAR PUSTAKA}

Abu Ahmadi, 1990. Strategi Belajar Mengajar Bandung: CV Pustaka Setia

Anton, M, Mulyono. 2001. Aktivitas Belajar. Bandung. Yrama.

Arikunto, Suharsimi., 2009, Dasar-dasar Evaluasi Pendidikan, Bumi Aksara, Jakarta.

Darsono, Max. 2001. Belajar dan Pembelajaran. Semarang : IKIP Semarang Press.

Depdiknas .2003. Undang-undang RI No.20 tahun 2003.tentang sistem pendidikan nasional. Jakarta : Depdiknas,

Depdiknas. 2003. Undang-undang No. 20 tahun 2003 Sistem Pendidikan Nasional Beserta Penjelasannya Yogyakarta: Pustaka Pelajar.

Depdiknas. 2005. Peningkatan Kualitas Pembelajaran. Jakarta: Depdiknas.

Dimyati, Mudjiono. 2002. Belajar dan Pembelajaran. Jakarta : Rineka Cipta. 
Wina Sanjaya., 2009. Kurikulum Dan Pembelajaran, jakarta : Kencana Prenada Media Group

Afnibar, Fajhriani. (2020). Pemanfaatan Whatsapp Sebagai Media Komuniaksi Antara Dosen dan Mahasiswa dalam Menunjang Kegiatan Belajar.

Alimuddin.Tawany Rahamma, dan M. Nadjib.2015.Intensitas Penggunaan E-Learning Dalam Menunjang Pembelajaran Mahasiswa Program Sarjana Di Universitas Hasanuddin. (http://95461-ID-intensitas-penggunaan-elearning-dalam-m, diakses 10 Februari 2020).

Astini, N. K. S. (2020). Pemanfaatan Teknologi Informasi dalam Pembelajaran Tingkat Sekolah Dasar pada Masa Pandemi Covid-19.LAMPUHYANG,11(2), 13-25.

Barhoumi, C. (2015). The effectiveness of WhatsApp mobile learning activities guided by activty theory on students' knowledge management. Contemporary Educational Technology, 6(3), 221-238. files.eric.ed.gov/fulltext/EJ1105764.pdf. Diakses 23 Desember 2016.

Bilfaqih, Y., Qomarudin, M.N., 2015. Esensi Penyusunan Materi Daring Untuk Pendidikan Dan Pelatihan. Yogyakarta: DeePublish

Mustofa, M. I., Chodzirin, M., \& Sayekti, L. (2019). Formulasi Model Perkuliahan Daring Sebagai Upaya Menekan Disparitas Kualitas Perguruan Tinggi. 151159

Hadisi, dan Muna. (2015). Pengelolaan Teknologi Informasi Dalam Menciptakan Model Inovasi Pembelajaran ( E-Learning ). Jurnal Al-Ta'dib, 8, 127-132.

Cahya A, Hendri.S, Imam.A, Retno. 2014. Analisis Tingkat Kontribusi Teknologi Dalam Produksi Keripik Buah Menggunakan Metode Technology Coefficien Contribution (TCC) di Kabupaten Malang. Malang: Jurnal, Universitas Brawijaya.

Lovy Herayanti, M. Fuadunnazmi, dan Habibi 2017) "Pengembangan Media Pembelajaran Berbasis Moodle Pada Matakuliah Fisika Dasar”. Mataram: FPMIPA IKIP Mataram

Wilujeng, Insih, Agus Setiawan, dan Liliasari. 2010. Kompetensi IPA Terintegrasi Melalui Pendekatan Keterampilan Proses Mahasiswa S-1 Pendidikan IPA. Jurnal Cakrawala Pendidikan No. 3.Yogyakarta:

Jumiatmoko. (2016). Jurnal Whatsapp Messenger Dalam Tinjauan Manfaat Dan Adab. $3(1,2,3): 52-54$

Kartika, A. R. (2018). Model Pembelajaran Daring. Journal of Early Childhood Care \& Education, 27

Chiappetta,E.L.,\&Koballa, T.R.(2010). Science Instruction in The Middle and Secondinary Schools Developing Fundamental Knowledge and Skills. USA: Pearson Inc.

187Eko Kuntarto (2017). Kefektifan Model Pembelajaran Daring Dalam Perkuliahan Bahasa Indonesia Diperguruan Tinggi" Journal Indonesian Language Education and Literature /ILE\&E/Vol.3 No. 1

Yamin, Martinis. 2007. Profesionalisasi Guru \& Implementasi KTSP. Jakarta: Gaung. Persada Press

J. Moleong, Lexy. 2000. Metode Penelitian Kualitatif. Remaja Rosdakarya; Bandung. 
Mustofa, M. I., Chodzirin, M., \& Sayekti, L. (2019). Formulasi Model Perkuliahan Daring Sebagai Upaya Menekan Disparitas Kualitas Perguruan Tinggi. 151 159

National Science Teachers Association. (2003). Standar for Science Teacher Preparation: $\quad$ Revised $2003 . \quad$ [Online]. Tersedia: http://www.nsta.org/pdfs/NSTAstandards2003.pdf. [2 September 2007]

W.J.S, Poerwadarminta (1992), Kamus Umum Bahasa Indonesia, Balai. Pustaka, Jakarta

Pranajaya, \& Hendra Wicaksono. (2017). Pemanfaatan Aplikasi WhatsApp (WA) Di Kalangan Pelajar (Studi kasus Di MTs Al Muddatsiriyah dan MTs jakarta Pusat). Prosiding SNaPP2017 Sosial, Ekonomi, Dan Humaniora, Vol 7, No.1 98-109.

Diakses darihttp://proceeding.unisba.ac.id/index.php/sosial/article/view/808

Raka Joni,T.(1992), Pokok-Pokok Pikiran Mengenai Pendidikan Guru, Jakarta: Ditjen Dikti Depdiknas

Rosarians, F., Warsono, A., Fikri, A., \& Permana, S. (2020, March 16). Belajar di Rumah Lewat WhatsApp. https://koran.tempo.co/read/metro/451002/belajar-dirumah-lewat-whatsapp?

Sanjaya (2007, h. 54) Wina Sanjaya. (2007). Strategi Pembelajaran Berorientasi Standar.Jakarta : Kencana, Prenada Media Group.

Sari, P. (2015). Memotivasi Belajar Dengan Menggunakan E-Learning. Jurnal Ummul Qura, 6, 28-29

Seno, \& Zainal, A. E. (2019). Persepsi Mahasiswa Terhadap Pelaksanaan E-Learning Dalam Mata Kuliah Manajemen Sistem Informasi. Jurnal Kajian Teknologi Pendidikan, 02, 183

Slameto. (2003). Belajar dan Faktor-faktor yang mempengaruhinya. Jakarta: Rineka Cipta.

Sukmadinata, Nana Syaodih. 2009. Metode Penelitian Pendidikan. Bandung : Remaja Rosdakarya

Sund, Robert B. \& Leslie W. Trowbridge. (1973).Teaching Science By Inquiry in The Secondary School. Second edition. London: Charles E. Merrill Publishing Company.

Suryadi, Edi. 2018. Strategi Komunikasi. Bandung: PT Remaja Rosdakarya.

Syaiful Sagala, 2003. Konsep dan Makna Pembelajaran Bandung : Alfabeta2

Trefil, James dan Hazen, Robert. 2007. The Sciences an Integrated Approach, Edisi ke6. USA:John Wiley \& Sons, Inc.

Wardani. 2009. Riset Sumber Daya Manusia. Jakarta : PT. Gramedia Pustaka Utama.

Winkel W.S. 1991. Psikologi Pengajaran. Jakarta: Grasindo

Yensy, N.A. 2012. Penerapan Model Pembelajaran Kooperatif Tipe Example Non Example dengan Menggunakan Alat Peraga untuk Meningkatkan Hasil Belajar Siswa di Kelas VIII SMP N 1 Argamakmur. Jurnal Pendidikan IPA dan Sains. Exacta. Vol. X No 1 Juni 2012. Jurusan PMIPA FKIP UNIB. 
AKSARA: Jurnal Ilmu Pendidikan Nonformal

P-ISSN 2407-8018 E-ISSN 2721-7310 DOI prefix $\underline{10.37905}$

Volume 08, (1), January 2022

http://ejurnal.pps.ung.ac.id/index.php/Aksara 